\title{
International Development Cooperation in the Fields of Water and Sanitation: A Comparative Study of the United States and the Spanish Approaches in Latin America and the Caribbean
}

\author{
Sergio Colina Martín \\ Escuela Diplomática / Diplomatic School, \\ Paseo de Juan XXIII5, Madrid, Spain
}

\begin{abstract}
In the last decade, the access to drinking water and sanitation have been acknowledged as human rights by the international community; they have also been recognized as a crucial goal for achieving sustainable development for all, in the framework of the 2030 Agenda. The need for international cooperation in those fields has gained new attention, and several multilateral actors and development agencies (including USAID and AECID) have consolidated or amplified their support to the WASH sector in developing countries. A comparative analysis of the different ways in which the United States and the Spanish cooperation conceive, design and implement their development programmes in Latin America and the Caribbean can contribute to a better understanding on the strategies to effectively protect and promote those human rights and to achieve SDG 6.
\end{abstract}

Keywords: water, sanitation, human rights, sustainable development, international cooperation

\section{Introduction}

In 2010, the United Nations General Assembly ${ }^{1}$ recognized the human right to water and sanitation, acknowledged that drinking water and sanitation are essential to the effective realization of all human rights (Brown et al. 2016) and urged States and other international actors to provide the needed resources (including financial aid, capacitybuilding and transfer of technology) to help countries, especially developing countries, to provide safe, clean, accessible and affordable drinking water and sanitation for all (Meier et al. 2014). That same year, the UN Human Rights Council adopted another resolution ${ }^{2}$ affirming that the right to water and sanitation are part of existing international law and confirming that these rights are binding upon States (De Albuquerque 2012). There were other subsequent significant resolutions on the human right to safe drinking water and sanitation $^{3}$, until the General Assembly ${ }^{4}$ recognized, in 2015, the distinct nature of the

\footnotetext{
${ }^{1}$ A/RES/64/292

${ }^{2}$ A/HRC/RES/15/9

${ }^{3}$ A/RES/68/157

${ }^{4}$ A/RES/70/169
} 


\section{Journal of International Cooperation and Development}

www.richtmann.org/journal

Vol 3, No 2, November 2020

right to sanitation in relation to the right to safe drinking water (Winkler 2016), while keeping these two rights tightly linked together ${ }^{5}$.

The discussion on the right to water had been going on for years (Gleick 1998). In 1999, the General Assembly had already approved a resolution affirming that "in the full realization of the right to development (...) the rights to food and clean water are fundamental human rights and their promotion constitutes a moral imperative both for national Governments and for the international community"6 (Scanlon et al. 2004). In 2002, the Committee on Economic, Social and Cultural Rights adopted General Comment No. $15^{7}$ on the 1966 International Covenant (ICESCR), framing the right to water (defined as the right of everyone to sufficient, safe, acceptable and physically accessible and affordable water for personal and domestic uses) within the fundamental right to an adequate standard of living, while stressing that it is inextricably associated to the right to the highest attainable standard of physical and mental health, as well as the right to life and human dignity ${ }^{8}$ (Cahill 2005).

This means that, at least for the last decade, international cooperation in the fields of the access to water and sanitation has taken place no longer as just another possible, voluntary contribution from technical and financial partners to the advancement of the situation in certain countries ${ }^{9}$, but in the framework of an international consensus that this is an obligation and an international commitment to the advancement of human rights ${ }^{10}$. Development cooperation programmes regarding water, sanitation and hygiene

${ }^{5}$ Previously to the adoption, several voices from the academia had been advocating for that differentiated approach, arguing that "the practical and social requirements for an environmentally sustainable and cost-effective implementation of access to water and sanitation are so different that, even if there is a combined right, the implementation may call for separating these two issues" (Obani \& Gupta 2015).

${ }^{6}$ A/Res/54/175

${ }^{7}$ For critiques and observations to the General Comment, cf.: Tully 2005; Thielböguer 2015; Brown and Heller 2017.

${ }^{8}$ Several other international human rights treaties explicitly mention the right to clean water and sanitation in relation to the rights to health, to adequate living conditions and to social protection, including the Convention for the Elimination of All Forms of Discrimination Against Women (Hellum 2017) and the Convention on the Rights of Persons with Disabilities (Groce et al. 2011).

${ }^{9}$ The importance for water and sanitation had been acknowledged much earlier than its recognition as a human right, as shown by the 1977 United Nations Water Conference in Mar Del Plata (Argentina), the Cairo's International Conference on Population and Development (1994), the 1996 United Nations Conference on Human Settlements (HABITAT II) in Istanbul, etc. (Kirschner 2011).

10 UN Special Rapporteur Albuquerque stated that, while many development policies had demonstrated political commitment to put WASH issues on the agenda, the human rights perspective could make a qualitative difference, since a rights-based approach does not rely on States' discretion, but sets legally binding obligations with specific standards to be achieved: https://sr-watersanitation.ohchr.org/en/rightstowater_6.html 


\section{Journal of International Cooperation and Development}

www.richtmann.org/journal

Vol 3, No 2, November 2020

(WASH) are undertaken no longer as a mere possible, politically interesting collaboration, or as a merely technical contribution, but in the framework of an international binding rule $^{11}$ (Aguilar Cavallo 2012) and of international accountability mechanisms, including through human rights treaty bodies (Meier \& Kim 2015). The recognition of water and sanitation as rights introduced an international legal dimension (not something desirable, but something mandatory), which binds States (at least, those who have ratified the ICESCR) and further consecrates the principles of equality and non-discrimination, thus placing a special emphasis on the most vulnerable people and the participation of people in the resource management processes (De Luis Romero et al. 2013). Our analysis will consider international development cooperation policies in the fields of water and sanitation as a central tool for the protection of two universal human rights that have been acknowledged and need to be fulfilled

In the specific context of the international development agenda, the work of international cooperation in the fields of water and sanitation has moved from the implementation of the Millennium Development Goals ${ }^{12}$ (WHO 2007; WHO 2012; Bautista Soto 2013) to the Sustainable Development Goals (SDG) included in the 2030 Agenda for Sustainable Development (UN-Water 2016). SDG 6 is specifically devoted to ensuring availability and sustainable management of water and sanitation for all, and includes 6 targets, referred to universal access to safe and affordable drinking water; equitable access to adequate sanitation and hygiene (Mara \& Evans 2018); the end of open defecation (Mara 2017), paying special attention to the needs of women and girls (Saleem et al. 2019) and those in vulnerable situations; improve water quality by reducing pollution (Ezbakhe 2018), eliminating dumping and minimizing release of hazardous chemicals and materials, halving the proportion of untreated wastewater and substantially increasing recycling and safe reuse globally (Tortajada 2020); substantially increase water-use efficiency across all sectors (FAO 2018) and ensure sustainable withdrawals and supply of freshwater to substantially reduce the number of people

\footnotetext{
${ }^{11}$ Even though some authors consider that it is still not possible to currently affirm the existence of a settled customary rule that generates obligations for states, but rather a practice that could be described as a custom in status nascendi that needs to be consolidated in a final codification (Álvarez Arca 2019).

12 In that framework, water and sanitation didn't have their own specific goal, nor were they linked to health: they were included in Goal 7, devoted to ensure environmental sustainability; more specifically, target 7.C called to "halve, by 2015, the proportion of people without sustainable access to safe drinking water and basic sanitation" (Weststrate et al. 2019). However, the UN system constantly recognized that "the combination of safe drinking water and hygienic sanitation facilities is a precondition for health and for success in the fight against poverty, hunger, child deaths and gender inequality" (WHO/UNICEF 2004). Moreover, the affordability criterion was not included in the target, despite the fact that the importance of affordability had already been recognized in a long line of international standards (Langford \& Winkler 2013).
} 


\section{Journal of International Cooperation and Development}

www.richtmann.org/journal

Vol 3, No 2, November 2020

suffering from water scarcity; integrated water resources management (Bertule et al. 2018), including through transboundary cooperation; and the protection and restoration of water-related ecosystems (Dickens et al. 2017). This common goal and targets imply an explicit call to expand international cooperation and capacity-building support to developing countries in water and sanitation-related activities and programmes, including water harvesting, desalination, water efficiency, wastewater treatment, recycling and reuse technologies and to support and strengthen the participation of local communities in improving water and sanitation management (Génevaux 2018).

As human rights, access to drinkable water and to sanitation are interrelated with all the rest of human rights (Neves-Silva et al. 2019), that are by definition interdependent and indivisible ${ }^{13}$; but WASH programmes play also a pivotal role from a sustainable development point of view ${ }^{14}$ : "Water is the common currency which links nearly every SDG, and it will be a critical determinant of success. Abundant water supplies are vital for the production of food and will be essential to attaining SDG 2 on food security; clean and safe drinking water and sanitation systems are necessary for health as called for in SDGs 3 and 6; and water is needed for powering industries and creating the new jobs identified in SDGs 7 and 8. None of this is achievable without adequate and safe water to nourish the planet's life-sustaining ecosystem services identified in SDGs 13, 14 and 15" (World Bank 2016).

Considering the current figures of aid from a general point of view, it would seem that the water and sanitation sector "is verifiably receiving increased attention and funding through international development cooperation" (Brown \& Heller 2017). The trends in the last decades have been summarized as follows: official development finance for water tripled between 2003 and 2014, rising from an annual allocation of $\$ 6$ billion in 2003 to close to $\$ 18$ billion in 2014 (coinciding with the implementation of the MDGs and the International Water Decade adopted by the UN); concessional loans for specific projects account for the bulk of ODF flows; the share of official development aid (ODA) to water as part of total ODA flows declined slightly, while $3 / 4$ of those flows were funneled via public sector agencies (Winpenny et al. 2016) ${ }^{15}$. Some NGOs underline that "finance is not reaching the poorest communities who do not have access to basic services" and that "investment is predominantly in large-scale sewerage systems and piped networks" (WaterAid 2008).

\footnotetext{
${ }^{13}$ See the Vienna Declaration and Programme of Action, adopted by the World Conference on Human Rights (1993).

14 "Progress in health and education is dependent on access to affordable sanitation and safe water", even if often donors have failed "to recognise the inter-relationship between these three essential services" (WaterAid 2008).

${ }^{15}$ For complementary and more detailed analysis, see OECD 2017.
} 


\section{Journal of International Cooperation and Development}

www.richtmann.org/journal

Vol 3, No 2, November 2020

The World Bank's International Development Association (IDA), Japan ${ }^{16}$, the EU and its member States and the United States (OECD 2013, Wateraid 2015) have traditionally been the leading donors in the field of water and sanitation. For a long time, Spain was cited among the countries that most significantly increased their aid to the water sector and among the donors that extended the highest proportions of their aid to the water sector (OECD 2010, OECD 2012). Spain, together with Japan, the Netherlands and Sweden, have been considered among the few countries to consistently have included the protection of the human rights to water and sanitation in their international development policies, while the Swiss ${ }^{17}$ and the German ${ }^{18}$ cooperation are often credited for the resources they have helped developed to facilitate a human rights approach in development projects (Brown \& Heller 2017).

Both Spain and the United States - and their respective development cooperation agencies, AECID and USAID - have put in place very relevant programmes devoted to water and sanitation, and they have done so based on very different normative frameworks, institutional structures, budgetary capacities, specific priorities and working methods. Comparing these two models might be particularly relevant to detect particular strengths and weaknesses, challenges and opportunities, in order to contribute to a better understanding on what has been done so far by the international development community and to ascertain what could be done to better ensure the fulfilment of the internationally-agreed shared goals by 2030 . This comparative study will be done in the theoretical assumption that international development cooperation must be led by the explicit objective of materializing significant contributions to the achievement of the SDGs (in this case, SDG 6) and, at the same time, by the obligation to contribute to protect and promote the human rights to water and sanitation, which calls for the implementation of rights-based approaches (OHCHR, 2006; ONGAWA, 2012) rooted on full inclusion and non-discrimination (UN-Water 2015) and systematic gender mainstreaming (Van WijkSijbesma 1998; Programa de Agua y Saneamiento 2002; UN-Water 2006; GWP 2006).

\section{The US Approach}

In 2017, the U.S. Department of State and the U.S. Agency for International Development (USAID) released the first U.S. Global Water Strategy (GWS). With contributions from more than 17 U.S. government agencies and departments, the Global Strategy lays out four interrelated objectives: 1 ) to increased access to sustainable safe drinking water and sanitation services, and to promote hygiene; 2 ) to protect freshwater resources; 3 ) to

${ }^{16}$ For more information of the Japanese approach to water and sanitation, see: JICA 2012; JICA 2017.

17 See COHRE 2007.

${ }^{18}$ See Levin 2019. 


\section{Journal of International Cooperation and Development}

www.richtmann.org/journal

Vol 3, No 2, November 2020

promote cooperation on shared waters; 4 ) to strengthen water governance and financing. The announced expected key outputs for those strategic objectives are the following: increased number of people in households and institutions with sustainable access to basic or safely managed drinking water and sanitation services, and decreased mortality/morbidity from causes linked to lack of drinking water, sanitation, and hygiene; increased access, quantity and quality of water supplies, economic growth, enhanced food security and ecosystems; improved preparedness for and resilience to water related disasters and future hydrometeorological changes; greater linkages between water programs and food security; increased number of cooperative events on water in priority regions; stable, adaptive, and responsive institutions that support the cooperative management of shared waters; improved policy, regulatory, and institutional environment at local and national levels; increased mobilization of public and private resources for water and sanitation; well-functioning international institutions, organizations, and partnerships that build global capacity and support the sustainable development and sound management of water resources (US Government 2017). It must be noted that, among the outputs, the Global Strategy also includes the creation of a "greater capacity of the United States to anticipate and meet domestic water challenges", even though it is clear that this cannot be taken an international development cooperation goal.

The Global Strategy is intended to be implemented through technical assistance, targeted investments in infrastructure and services, mobilizing financial resources and promoting science and technology, combined with diplomatic engagement and the strengthening of partnerships with intergovernmental organizations. Coordination is expected to be ensured, in Washington, through an Interagency Water Working Group; on the field, in developing countries, it is meant to be channelled through the U.S. Missions.

The vision announced by the strategy is "a water secure world, where people have sustainable supplies of water of sufficient quantity and quality to meet human, economic, and ecosystem needs while managing risks from floods and droughts", with the aim to "reduce disease and save lives, eradicate poverty, and promote sustainable economic growth, increase food and energy security, build peace and security (...)" (US Government 2017). The work on water and sanitation is therefore linked to health, food needs and the fight against poverty, on the one hand, but also to security (Busby 2017) - with several references to "peace and security", "energy security", risk management...- and economic growth on the other. At the same time, it clearly makes explicit the will to "open up international markets to U.S. technologies and approaches"; moreover, the U.S. international engagement is expected to "cultivate opportunities to strengthen water security in the United States". No mention to the access to water and sanitation as human rights is included. There is also no reference at all to the SDGs or the 2030 Agenda.

Previously to the approval of this inter-agency global plan, USAID had its own specific 


\section{Journal of International Cooperation and Development}

www.richtmann.org/journal

Vol 3, No 2, November 2020

strategy. In 2012, USAID the Office of Water and a Global Water Coordinator. It was located within the Bureau for Economic Growth, Education and Environment and tasked to lead water programming across the Agency, in close coordination with other relevant Washington bureaus and offices -including the Bureau for Global Health, the Bureau for Food Security, and the Global Development Lab (Ingram 2014) - and in dialogue with priority country Missions. The Office also collaborates with a variety of private sector, international donor agencies, financial institutions and NGO stakeholders to work towards integrated programming.

Afterwards, the Agency launched its first Water and Development Strategy, with the objective "to save lives and advance development through improvements in water supply, sanitation and hygiene (WASH), and sound water management for food security" (USAID 2013a). The strategy designated priority countries (mainly in Africa and Asia) for assistance based on "greatest needs and opportunities". When it was launched, it announced the following objective: by 2018, the Strategy should have led to providing 10 million people with sustainable access to an improved drinking water source, 6 million people with sustainable access to an improved sanitation facility, and improved management of water for agriculture sustainably and productively to enhance food security benefiting 2 million people (USAID 2013a). When the Global Water Strategy was launched, USAID announced that it would contribute to its implementation by providing 15 million people with sustainable access to safe drinking water services and 8 million people with sustainable access to sanitation services (US Government 2017).

The programming of US international development cooperation programmes on water and sanitation is aligned and included in a broader normative and strategic framework. This does not only include the above-mentioned GWS, but also some specific laws devoted to this matter. In 2005, Congress passed the Water for the Poor Act, which reinforced water and sanitation as a foreign affairs priority. Since then, USAIDS' portfolio in this field saw its annual directive requirements growing from $\$ 295 \mathrm{M}$ in 2008 to $\$ 400 \mathrm{M}$ in 2016. In 2014, the Water for the World Act was approved, calling for more targeted, effective and sustainable investments for WASH projects to most-in-need countries.

\section{The Spanish Approach}

In Spain, water management has traditionally played a crucial role in national policy. Subsequently, it has consolidated also as a key line of work in the international arena. In the multilateral sphere, Spain was one of the leading member States to promote the acknowledgement of the human rights to water and sanitation by the UN and the establishment of the Special Rapporteur, and it supports the Sanitation and Water for All (SWA) initiative ${ }^{19}$. Water has also been a central issue in the Spanish foreign policy

${ }^{19}$ https://www.sanitationandwaterforall.org/news/swa-welcomes-spain-partnership 


\section{Journal of International Cooperation and Development}

www.richtmann.org/journal

Vol 3, No 2, November 2020

towards the Mediterranean (Sorroza 2014) and Latin America -for example, through the Spain-Latin America Dialogues on Water, jointly organized by CAF-Development Bank of Latin America and the different Spanish Ministries working on water-related issued, including the Minister of Foreign Affairs and Cooperation-. Water and sanitation have been at the core of its development cooperation policies towards Latin America and the Caribbean (LAC) -through the Cooperation Fund for Water and Sanitation (FCAS) - and, more recently, it has also been identified as a strategic field of development cooperation with North Africa and the Arab countries - through the MASAR Water programme ${ }^{20}$.

Until recently, Spain did not have a stable institutional and strategic architecture to ensure strong articulation between the domestic and the international dimensions of water and sanitation policies, often leaving coordination and synergies between the different relevant public actors to ad hoc mechanisms. However, the holistic approach fostered by the 2030 Agenda, and the strong commitment of Spain to the swift incorporation of SDGs into all public policies, has helped to overcome the previous lack of a "global strategy" that could be compared to the one approved by the US government. In its overview of SDG 6, the Spanish Action Plan for the Implementation of the 2030 Agenda $^{21}$ (that underlines universal and equitable access to water and sanitation in Spain, as well as the quality of water and its efficient and sustainable management at a national level) includes an explicit reference to the international dimension. In this sense, it mentions the will to strengthen cooperation policies, especially in the framework of the Cooperation Fund for Water and Sanitation and of the Fund for the Promotion of Development (FONPRODE) ${ }^{22}$, to build capacities in all programs related to water (from catchment and distribution to its use and treatment), and specifically refers to two flagship initiatives promoted by Spain in this field ${ }^{23}$ : the Conference of Ibero-American Water Directors (CODIA $)^{24}$, of which Spain holds the Permanent Secretariat, and the Water Strategy for the Western Mediterranean, within the so-called $5+5$ Dialogue $^{25}$.

The $5^{\text {th }}$ Master Plan of the Spanish Cooperation prioritized targets 6.1, 6.2 and 6.5 to effectively contribute to the achievement of SDG 6 , and therefore established as main

\footnotetext{
${ }^{20}$ https://www.aecid.es/CentroDocumentacion/Documentos/Divulgaci\%C3\%B3n/Comunicaci\%C3 $\%$ B3n/Folleto_MASAR_200x200_baja.pdf

${ }^{21}$ Approved by the Spanish government in June 2018.

22 The main Spanish instrument for financial development cooperation, managed by AECID: https://www.aecid.es/EN/aecid/fonprode/general-information

${ }^{23}$ The Spanish Cooperation also supports and participates actively at the Ibero-American Network of Climate Change Offices (RIOCC), the Conference of Directors of Ibero-American Meteorological and Hydrological Services (CIMHET) and the Latin American Network of Knowledge Centers for Water Resources Management (RALCEA).

${ }^{24}$ https://codia.info/

${ }^{25}$ Which includes Spain, France, Italy, Malta, Portugal, Algeria, Libya, Morocco, Mauritania and Tunisia: https://medthink5plus5.org/en/the-dialogue-55/
} 


\section{Journal of International Cooperation and Development}

www.richtmann.org/journal

Vol 3, No 2, November 2020

priorities for the period 2018-2021 the following: expand the coverage of drinking water services and of sanitation (including wastewater treatment, connections to sewage and collection systems, solid waste collection systems), with a focus on expanding the network of services through the construction of infrastructure while strengthening the capacities for planning these actions; b) support water governance and comprehensive water resources management through the development of public policies, legislative frameworks, stronger institutions at all levels (including the decentralized entities and basin and micro-basin organizations) and the fostering of community water management systems in rural areas that include a strong component of public participation (MAEC 2018).

Moreover, the Master Plan states that "Spain's greatest added value in the field of water is experience in managing scarcity' and that the Cooperation Fund for Water and Sanitation (FCAS) has been the most important instrument of the Spanish Cooperation for progress in achieving these rights in LAC. The Spanish government announced its creation at the XVII Ibero-American Summit, held in November 2007 in Santiago de Chile; after a process of institutional design and consolidation, it began its activities in 2009.

The FCAS focuses in granting non-reimbursable aid and, where appropriate, untied loans, aimed at financing projects in the fields of water and sanitation, under a cofinancing regime with the national authorities of the countries prioritized by the Spanish cooperation. The FCAS can fund the cost of technical assistance for the drafting of projects and studies, the execution of works, the evaluation, monitoring, inspection and technical assistance of the various projects fostered by to the Fund, and, in general, all those works necessary to ensure their viability and economic, social and environmental sustainability. In the case of projects considered for possible financing, the Fund may also finance identification costs or feasibility or impact studies ${ }^{26}$.

Around 800 million euros have been disbursed so far by Spain in donations that have built, along with the contributions of the local counterparts, a portfolio of more than 1,660 million euros. The Fund has enabled water and sanitation programs and projects to be launched in 18 partner countries in the LAC region, prioritizing the provision of sustainable water and basic sanitation services, the provision of adequate infrastructures for populations that lack access to those services, and assistance in establishing public, efficient, transparent and participatory management systems, while strengthening the institutions and public bodies dedicated to water resource management, always a through a human rights-based approach to WASH. The FCAS estimates to have reached more than 3,3 million beneficiaries (around 2,7 million people through drinking water projects and more than 1,2 million people in sanitation programmes).

The FCAS actions are firmly rooted in the mobilization -in collaboration with the Ministry for Ecological Transition and other relevant departments - of technical expertise

${ }^{26}$ https://www.boe.es/buscar/act.php?id=BOE-A-2009-15439 


\section{Journal of International Cooperation and Development}

www.richtmann.org/journal

Vol 3, No 2, November 2020

from leading Spanish public entities such as TRAGSATEC, the Center for Hydrographic Studies $^{27}$, the Centre for New Water Technologies (CENTA) ${ }^{28}$ or the Geological and Mining Institute of Spain ${ }^{29}$, as well as Spanish universities and development NGOs and the collaboration of service providers such as the Spanish Association of Water Supply and Sanitation (AEAS) and other stakeholders from the private sector.

The Fund is managed by the Spanish Agency for International Development Cooperation (AECID) ${ }^{30}$ - through its Directorate for Cooperation with Latin America and the Caribbean, where the Department of the Cooperation Fund for Water and Sanitation is framed- and has two main modes of action: the bilateral, which is channeled directly through the cooperation relationships between AECID and partner countries; and the multilateral, which is managed in collaboration with the Inter-American Development Bank (IDB) ${ }^{31}$. All the actions are based on AECID's country strategies and agreed joint frameworks of cooperation, and therefore are also aligned with the policies and priorities of the partner countries. The Alliance between the Spanish cooperation and the IDB is conceived as a synergy between AECID's focus on the defense of access to water as a human right and on the relevance of citizens' participation ${ }^{32}$ and gender equality ${ }^{33}$ with the bank's technical expertise and strong capacities in terms of project management. The Spanish Cooperation has also put collaboration with the European Commission and the participation in European programmes and the implementation of EU funds ${ }^{34}$ at the core of its action regarding water and sanitation.

The Fund is also replenished through reimbursements of non-executed programs and

\footnotetext{
${ }^{27}$ Which is part of CEDEX, the Centre for Studies and Experimentation for Public Works, currently ascribed to the Ministry of Transportation, Mobility and Urban Agenda.

${ }^{28}$ Research institution promoted by the Regional Government of Andalusia.

${ }^{29}$ Currently ascribed to the Ministry of Science and Innovation.

${ }^{30}$ https://www.boe.es/buscar/doc.php?id=BOE-A-2008-10709

${ }^{31}$ These contributions are channeled mainly through the Spanish Cooperation Fund for Water and Sanitation in Latin America and the Caribbean (AECID 2016). The FECASALC is a trust fund established between the Government of Spain and the IDB, and through multi-donor trust funds such as AquaFund, managed by the IDB: https://www.iadb.org/en/sector/water-initiatives.

32 There is a consensus that "increased civil society engagement can serve as a vehicle to integrate social and environmental goals in approaches to water management, and as an instrument of accountability. It will help ensure involvement and ownership of decisions by local populations and address the needs of the poor, the people whose opinions and ideas are most often muted in development decisions" (Krchnak 2005).

${ }^{33}$ A strong commitment to the full incorporation of a consistent gender approach to water and sanitation policies is crucial since "WASH is one of the most critical challenges to women's empowerment: lack of access prevents girls and women from getting an education, entering the labor force, growing sufficient food, and protecting themselves from disease and sexual violence" (WaterAid 2011).

${ }^{34}$ So far, around 80 million euros from the EU budget have been implemented by the FCAS.
} 


\section{Journal of International Cooperation and Development}

www.richtmann.org/journal

Vol 3, No 2, November 2020

reimbursed loans, which allows to finance additional lines of work such as putting in place complementary actions to enhance the sustainability of the programs, fostering strategic interventions in water planning and basin management, providing additional technical cooperation and supporting innovative initiatives that emphasize certain strategic value lines for the partner countries and that may be later replicated in other contexts. The FCAS budget by the end of 2019 was of approximately 801,3 million euros (around 403,65 million in bilateral programmes and 397,68 million in multilateral programmes).

\section{The Specific Work of USAID and AECID in Latin America and the Caribbean}

Latin America and the Caribbean shows "significant regional heterogeneity and elevated inequality in access to services" related to water and sanitation (Carvalho Queiroz et al. 2020). 34 million people do not have access to improved water sources while 63.8 million people do not have access to adequate sanitation; in rural areas, safe sanitation coverage is barely $26 \%$, and in urban areas it does not reach $50 \%$; the region only treats $20 \%$ of wastewater (AECID 2018a).

According to the Global Water Strategy, the U.S. efforts on this field focuses on "highpriority countries where needs and opportunities are greatest" and where "engagement can best protect" the U.S. "national security interests". These countries include Afghanistan, the Democratic Republic of Congo, Ethiopia, Ghana, Haiti, India, Indonesia, Kenya, Lebanon, Liberia, Madagascar, Mali, Mozambique, Nigeria, Nepal, Senegal, South Sudan, Tanzania and Uganda; Jordan and Lebanon are designated as "strategic-priority countries because of a combination of national-security considerations and development needs" (U.S. Government 2017). Therefore, only Haiti is considered a high-priority country in the LAC region; however, USAID also funds water projects in Guatemala, Honduras and Peru. USAID activities in Peru focus on building the country's capacity to adapt to climate change and improve water security, including through climate science and innovation. Specific programs such as the Natural Infrastructure for Water Security project support green infrastructures to manage fluctuations in the water supply. USAID facilitates professional exchanges between Peruvian and American scientists working for the public administration to identify innovative research-based strategies to address the effects of climate change. In Guatemala, USAID focuses on strengthening the capacity of municipal water service providers to develop strategic business and investment plans and collaborating with other municipalities to map water boundaries and define the provision of water services and the management of water resources.

As far as the Spanish cooperation is concerned, the FCAS has always concentrated all its activities in the LAC region, currently throughout 18 eligible countries: Bolivia, Brazil, Chile, Colombia, Costa Rica, Cuba, the Dominican Republic, Ecuador, El Salvador, Guatemala, Haiti, Honduras, Mexico, Nicaragua, Panama, Paraguay, Peru and Uruguay (AECID 2017c). In general terms, it focuses on working in rural and peri-urban areas with 


\section{Journal of International Cooperation and Development}

www.richtmann.org/journal

Vol 3, No 2, November 2020

less access to drinking water and sanitation services, with the aim of closing the gap between these areas and urban areas, which generally have greater coverage or more possibilities of obtaining it. In Honduras, the FCAS has so far approved eight interventions in (seven bilateral and one multilateral programmes), with 45.7 million euros of Spanish donations; AECID estimates that almost 100,000 people have benefited. The interventions focus mainly on areas of the country's Dry Corridor, with special emphasis on peri-urban areas in intermediate cities and on a dispersed rural population that did not have access to potable water and sanitation services, and whose management is carried out through Community Water Boards; support for decentralization in water management, after legal changes enhancing the assumption of powers by the municipalities, has also played an important role $^{35}$. The objectives of the Fund in Peru concentrate on extending the coverage of drinking water and basic sanitation systems in rural communities, in small towns and in marginal areas of medium-sized cities, with a strong focus on ensuring the future sustainability of services through the strengthening of institutional and management capacity of water and sanitation services of community organizations, municipal management units, etc.

Haiti is the country that receives most funding from the FCAS (almost 120 million euros up to date), followed by Bolivia (95,5 million) and Paraguay (72 million) ${ }^{36}$.

\section{One Paradigmatic Example: The Case of Haiti}

Access to water and sanitation in Haiti is still the lowest in the Western Hemisphere (Gelting et al. 2013). Considering indicators such as the proportion of people without minimum access to water, sanitation and hygiene services, national resource availability and overall levels of poverty, Haiti has consistently been considered as the priority country for international cooperation in the fields of water and sanitation in the LAC region (WaterAid 2015). The Inter-American Development Bank and the World Bank among international financial institutions, and the United States and Spain among bilateral donors, are among the leading technical and financial partners of Haiti in this field.

The US foreign action in the Caribbean is framed by the premise, stated in the, that "the Caribbean region is the United States' 'third border', characterized by common interests and societal ties that yield daily, tangible benefits for U.S. citizens" (Department of State, 2019). USAID states it is addressing Haiti's challenges by building water and sanitation infrastructure, increasing capacity to manage service delivery, and improving the enabling environment for the sustainable implementation, operation, and maintenance of water and sanitation services, and that the guiding principles within the portfolio include: 1) aligning with the country strategies, including Haiti's Cholera-

\footnotetext{
${ }^{35}$ https://desarrollo.socialco.es/aecid/fondoagua2019/honduras-ampliado/

${ }^{36}$ https://desarrollo.socialco.es/aecid/fondoagua2019/de-un-vistazo/
} 


\section{Journal of International Cooperation and Development}

www.richtmann.org/journal

Vol 3, No 2, November 2020

Elimination Plan; 2) supporting decentralization within the sector; 3) using market-based approaches, where feasible, and building private-sector capacity; and 4) increasing emphasis on sanitation, including the safe disposal of waste (USAID 2016).

The primary USAID activity to support these investments is the $\$ 44$ million Haiti WASH Project, which works in priority cholera hotspots and areas that are recovering from cyclical disasters ${ }^{37}$. Other USAID activities focus on rehabilitating water-supply systems, promoting hygiene behavior change through community health workers and mass media, and supporting the promotion and sales of socially marketed household water treatment products (USAID 2016). According to the USAID Water and Development Country Plan for Haiti ${ }^{38}$, in addition to USAID's development programming, the US Office of Foreign Disaster Assistance (OFDA) and the Centers for Disease Control and Prevention (CDC) of the U.S. Department of Health have also focused on response efforts in Haiti: OFDA supported efforts to prevent the spread of cholera in 2010-2011 (and again immediately following Hurricane Matthew) by providing logistics support and relief commodities, while CDC supports surveillance and response activities and has funded cholera and WASH interventions to support the involvement of local health workers in these activities (Bliss \& Fisher 2013). USAID expects to provide more than 250,000 Haitians with sustainable access to basic water supplies and help 75,000 Haitians gain access to basic sanitation by 2022 (USAID 2018).

In the case of Spain, water and sanitation has long been one of the top priorities of the Spanish development cooperation with Haiti (MAEC 2006). This decision is justified in a series of reasons, including: that Spain is international acknowledged for the management model of its water resources and the basic water and sanitation services; that it has been an intensive sector in specialized technical support and with potential to articulate technical capacities from Spain in sanitation, environmental impact and commercial management; that the potential impact on the improvement of the living conditions of the population is exponential; and that both local and international partners present in Haiti valued water and sanitation as the sector with the greatest comparative advantage by the Spanish Cooperation (MAEC 2015).

Haiti's portfolio is the most important in the FCAS, with a currently ongoing active bilateral program and four multilateral programs already completed (implemented with the Inter-American Development Bank and the Government of Haiti), and a total budget that exceeds 119 million euros in donations by the Spanish cooperation. Besides the infrastructure and construction component, the FCAS has focused in institutional strengthening actions of the National Direction of Potable Water and Sanitation and its decentralized entities, in the capital but also mainly in intermediate and rural cities (with important efforts to ensure the supply of drinking water to large cities such as Cap Haitien,

\footnotetext{
${ }^{37}$ https://www.globalwaters.org/wherewework/latinamericacaribbean/haiti

${ }^{38}$ https://files.globalwaters.org/water-links-files/Haiti\%20Country\%20Plan\%20final.pdf
} 


\section{Journal of International Cooperation and Development}

www.richtmann.org/journal

Vol 3, No 2, November 2020

Hinche, Jérémie, Miragoane, Saint-Louis-du-Nord, Fort Liberté, Mirebalais, Aquin, Petit Goave, Cabaret and Arcahaie). In rural areas, the FCAS work is mainly focused on the rehabilitation of a dozen water supply networks, in addition to sanitation and hygiene campaigns; in the capital, efforts are focused on improving drinking water services and sanitation coverage. AECID estimates that, through the almost 120 million euros that Spain has invested in Haiti through the FCAS, it has managed to leverage more than 35 million in local investments ${ }^{39}$.

\section{Conclusions}

Through the analysis of the legal, institutional, strategic and operational framework that the United States and Spain have in place for the programming and implementation of their international development cooperation action in the fields of water and sanitation in Latin America and the Caribbean, it is possible to underline some elements and to draw some conclusions that can help to better understand the strengths and weaknesses of the architectures set up by two very relevant actors in the chosen field of study. As announced in the introduction, the comparative analysis will be oriented to better understand how these two different models respond not only to the basic principles of alignment, coordination, harmonization, ownership and accountability, but also to a human rights approach to water and sanitation and to the effective achievement of the international commitments embedded in the 2030 Agenda for Sustainable Development.

First of all, the fact that the US has a Global Water Strategy that is anchored in several Acts passed specifically on international cooperation in the field of the water, and that USAID's Water and Development Strategy had an Implementation Field Guide operationalized through country specific strategies, provides a comprehensive and soundly interlinked normative and strategic architecture at all levels. However, the US Government's Global Strategy, despite having been approved in 2017, does not include any reference to the SDGs; human rights are also completely absent from its announced goals and guiding principles. Spain has historically lacked high-level norms that specifically address international cooperation in water and sanitation and, more generally, of strategic interdepartmental documents able to interlink in a comprehensive manner the national and international dimensions of water and sanitation. The Spanish International Development Cooperation Act (approved in 1998) does not mention water at all, even though it has been partially modified and updated several times since it was passed; moreover, it only refers to sanitation in the general framework of social services (article 7.a.). However, the Spanish Government's Action Plan for the Implementation of the 2030 Agenda (2018) corrects that tendency and provides an opportunity for putting in place a sounder normative architecture that could strengthen coordination among all public

${ }^{39}$ https://desarrollo.socialco.es/aecid/fondoagua2019/haiti/ 


\section{Journal of International Cooperation and Development}

www.richtmann.org/journal

Vol 3, No 2, November 2020

Spanish actors in the fields of water and sanitation and provide overarching orientation for the specific programming of the development cooperation actions and strategies.

Secondly, the US external action on water and sanitation seems to present a diffuse geographic prioritization, part of which reveals interests that seem more related to security and to other matters unrelated to development objectives. Regarding the objectives, the Global Water Strategy worries mainly that "a growing global water crisis (...) may increase disease, undermine economic growth, foster insecurity and state failure, and generally reduce the capacity of countries to advance priorities that support U.S. national interests" (US Government, 2017), and announces that "the United States will focus its efforts on countries and regions (...) where U.S. engagement can best protect our national security interests". Regarding the geographical focus, this translates into a relatively small presence in Latin America and the Caribbean, despite the proximity of Latin America and despite officially considering the Caribbean as "the United States" 'third border'" (Department of State, 2019).

This contrasts with the total focus on the LAC region by the Spanish FCAS, which has allowed the Spanish cooperation to position itself as a leader partner in the American continent and to maximize the development impact of the accumulated specific knowhow. Moreover, this qualitative difference combines with the concentrated quantitative effort that Spain decided to make in some contexts; the case of Haiti gives a clear example of how the Spanish cooperation, that has a much smaller total budget than USAID, has opted for a strong, focused commitment to contribute to ensuring the protection and promotion of the human rights to water and sanitation in the prioritized countries of the LAC region.

Both the US and the Spanish documents stress the need for alignment with national strategies and harmonization with other partners and donors' actions. However, the Spanish approach has always been focused on strengthening partner countries' capacities for effectively providing water and sanitation services, as well as ensuring the participation of beneficiaries and civil society, as a way to promote sustainable development through the protection and promotion of the rights to water and sanitation. As a consequence, it has come to acknowledge the need to engage with the private sector, both the Spanish (in order to mobilize additional resources and know-how) and the local one (in order to contribute effectively to inclusive economic growth and sustainability). On an opposite logic, the US acknowledges the need to work on water governance, but its approach seems to give a higher importance to market/private sector-oriented action. USAID's Water and Development Strategy 2013-2018, for instance, mentions 12 times the words "private sector", repeatedly insists on "marketing needs" and refers several times to the concept of "managing systems like a business" (USAID 2013a). But it does so not only in terms of mobilizing US private sector's resources and expertise to obtain higher development impacts in developing countries, but also in terms of national gain or domestic profit. The US Global Water Strategy enounces explicitly the following strategic 


\section{Journal of International Cooperation and Development}

www.richtmann.org/journal

Vol 3, No 2, November 2020

goal: "the United States benefits directly from engaging on international water issues. U.S. technologies, experience, and best practices are in high demand, which presents an opportunity for the U.S. private sector (...). Demonstrating U.S. approaches and technologies globally can increase U.S. exports and jobs. Work on water globally gives us access to knowledge and expertise that can help us address water related challenges at home" (US Government 2017). Some authors have referred to a stream of neoliberal economic strategies being one central competing ideology for water management in the U.S. Administration (Laituri et al. 2010).

Neither the Water and Development Strategy nor its Implementation Field Guide (USAID 2014) mentioned the idea of "human rights"; there is only one reference to listening to women in order to consider their needs and rights ${ }^{40}$ (USAID 2013a) and one reference to the fact that the GWS should be considered as "aligned and complementary" with the Agency's Strategy on Democracy, Human Rights and Governance (USAID 2013b). As a matter of fact, as specific human rights-based approach regarding water and sanitation policies continues to be missing in more recent documents (USAID 2019). Meanwhile, the Sectoral Action Plan for Water (AECID 2010) already established, a decade ago, that all AECID interventions in this sector must be designed with a comprehensive and multi-sectoral approach that incorporates the integral management of the resources and the challenges of access to water and sanitation in compliance with the internationally agreed development goals (at that time, the MDGs) and with a clear focus on human rights. This was summarized in the Action Plan around three guiding principles: comprehensive management of water resources, access to water and sanitation as a human right and strengthening local governance accordingly; but also through a series of cross-cutting approaches that stressed the need to take on board gender equality, environment and climate change, cultural diversity and health in interventions in the water and sanitation sector.

How has the FCAS been working recently on fostering a strong human rights-based approach and water sanitation? Just to point out some relevant initiatives, AECID has promoted the publication of several groundbreaking analysis and tools on the enforceability of the human rights to water and sanitation and its practical implementation in development projects (AECID 2017a, AECID 2017b); it has also developed a close partnership with the United Nations Special Rapporteurs on the human rights to drinking water and sanitation (first Catarina de Albuquerque ${ }^{41}$, more recently Léo Heller), supporting its work and facilitating the incorporating of his analysis in relevant

40 "The Strategy supports USAID efforts to improve agricultural water management by promoting transparency and inclusiveness, paying particular attention to elevating the voice of women and their rights and address their specific and unique needs in this process" (USAID 2013, p. 14).

${ }^{41}$ Several relevant documents produced by the Special Rapporteur, such as the compiling of good practices (2012) or the practical handbook for achieving the rights to water and sanitation (2014) were published and translated with the support of the Spanish Cooperation. 


\section{Journal of International Cooperation and Development}

www.richtmann.org/journal

Vol 3, No 2, November 2020

international and regional fora. In contexts with a high percentage of indigenous population (such as Panama, Paraguay, Peru, Ecuador or Guatemala), the programs have been accompanied by intensive awareness-raising actions with an intercultural approach, in order to help promote behavioral changes towards best practices and increase acceptability and sustainability of services, especially when working in sanitation and hygiene. Moreover, in some programs (mainly Nicaragua, Paraguay and Panama), the institutional capacities for gender mainstreaming have been strengthened, and the specific training of women leaders, who are currently part of the entities that operate water at the community level, has been fostered. Through the launch of a number of Schools for Women Leadership and Training and Empowerment Programs, the number of women assuming positions of responsibility on those boards has been significantly increased. This approach allows to overcome theoretical discussions about the relative importance of a formal articulation of a right to water compared to the impact of the existence of adequate mechanisms of governance (Anand 2007) by combining both, and thus ensuring an effective, participatory and inclusive governance rooted in a human rights-oriented approach. Only a clearer consideration of the effective and systematic inclusion of persons with disabilities seems to be still lacking from the Spanish strategies, programmes and projects (MAEC 2017, AECID 2018b).

For a long time, the general perception was that "States, policymakers, international development partners and civil society groups working in the water and sanitation sector have often proved slow to act when it comes to making the right to drinking water and sanitation a reality" (Levin et al. 2009). As other analysis have underlined, "a review of major funders' official policies for development cooperation in the sector suggests that many only partially endorse the frameworks for the human rights to water and sanitation", while "an observation of development cooperation flows to the sector allows the hypothesis to be advanced that worldwide inequalities in access to these services may be reduced through a full and clear application of the human rights framework in development cooperation activities" (Brown \& Heller 2017). Some authors have analyzed the practical needs for translating international human rights standards into local water and sanitation practices, and have concluded that "system operators, utilities, and management boards remain largely unaffected by the changing public policy landscape for human rights realization", so that to really understand "the relevance of human rights standards to water and sanitation practitioners", there is need for further research and stronger commitment by leading actors "to ensure that human rights aspirations lead to public policy reforms and public health outcomes" (Meier et al. 2014).

While the US has a sound legal framework regarding international action for water and sanitation and has devoted, in general terms, substantial budgets to WASH, the disconnection of its development cooperation policies with the recognition of human rights to water and sanitation and to the SDGs, the tendency to consider water "as a market commodity rather than as a human right" (Conca 2008) and the priority given to 


\section{Journal of International Cooperation and Development}

www.richtmann.org/journal

Vol 3, No 2, November 2020

goals that are alien to promoting sustainable development in partner developing countries, jeopardizes the effectiveness of its action and casts a shadow of doubt on its potential leading role in the global development community. Spain has compensated the limited figures, in general terms, of its ODA, with a clear geographical focus that has helped maximize the impact of interventions and the accumulation of specific know-how and capacities. It has also proven a consistent and credible commitment to the advancement of the human rights to water and sanitation and to the implementation of the MDGs and the 2030 Agenda. The holistic approach of this agenda, which calls for the achievement of the SDGs both at the national and the international levels, offers an opportunity to reshape the Spanish strategic framework in order to make it consistent to the importance given to WASH in the development cooperation with the LAC regional and to enhance interdepartmental coordination and the optimization of synergies among relevant actors.

\section{References}

AECID. Plan de Actuación Sectorial de Agua. Madrid: Agencia Española de Cooperación Internacional para el Desarrollo; 2010. https://www.aecid.es/galerias/quehacemos/descargas/AF_AGUA_AMPLIADA.pdf

AECID. Informe anual 2015. Fondo de Cooperación para Agua y Saneamiento. Madrid: Agencia Española de Cooperación Internacional para el Desarrollo; 2016.

AECID. Exigibilidad de los derechos humanos al agua y al saneamiento. Madrid: Agencia Española de Cooperación Internacional para el Desarrollo; 2017a. https://www.aecid.es/CentroDocumentacion/Documentos/FCAS/Generales/exigibilidad-web.pdf

AECID. Checklist. Guidelines on respect for the Human Right to Water and Sanitation in development projects. Madrid: Agencia Española de Cooperación Internacional para el Desarrollo; 2017b. https://www.aecid.es/Centro-Documentacion/Documentos /Divulgaci\%C3\%B3n/Comunicaci\%C3\%B3n/04_09_17_8Lista_Comprobacion_en.pdf

AECID. Informe anual 2017. Fondo de Cooperación para Agua y Saneamiento. Madrid: Agencia Española de Cooperación Internacional para el Desarrollo; 2017c. https://www.aecid.es/Centro-Documentacion/Documentos/FCAS/Generales /FCAS\%20INFORME\%20ANUAL\%202017\%20online.pdf

AECID. Informe anual 2018. Fondo de Cooperación para Agua y Saneamiento. Madrid: Agencia Española de Cooperación Internacional para el Desarrollo; 2018a.

AECID. Guía para la inclusión de la discapacidad en cooperación para el desarrollo. Estado de Situación en la AECID y orientaciones. Madrid: Agencia Española de Cooperación Internacional para el Desarrollo; 2018b.

Aguilar Cavallo G. The Human Right to Water and Sanitation: From Political Commitments to Customary Rule? Pace Int'l L. Rev. Online Companion, April 2012; 136. https://core.ac.uk/reader/46711014

Álvarez Arcá I. La necesaria codificación del derecho humano al agua y el saneamiento. Cuadernos Electrónicos de Filosofía del Derecho 2019; 39: 239-254. https://ojs.uv.es/index.php/CEFD/article/view/13954/pdf 


\section{Journal of International Cooperation and Development}

www.richtmann.org/journal

Vol 3, No 2, November 2020

Anand P.B. Right to water and access to water: an assessment. Journal of International Development 2007; 19(4), 511-526. https://doi.org/10.1002/jid.1386

Bautista Soto J. El derecho humano al agua y al saneamiento frente a los Objetivos de Desarrollo del Milenio. Santiago de Chile: CEPAL; 2013.

Bertule M, Glennie P, Bjørnsen P.K, Lloyd G.J, Kjellen M, Dalton J, Rieu-Clarke A, Romano O, Tropp H, Newton J, Harlin J. Monitoring Water Resources Governance Progress Globally: Experiences from Monitoring SDG Indicator 6.5.1 on Integrated Water Resources Management Implementation. Water 2018; 10(12): 1744. doi:10.3390/w10121744

Bliss K.E, Fisher M. Water and Sanitation in the Time of Cholera: Sustaining Progress on Water, Sanitation and Health in Haiti. Washington DC: Center for Strategic and International Studies; 2013.

Brown C, Neves-Silva P, Heller L. The human right to water and sanitation: A new perspective for public policies. Ciencia \& saude coletiva 2016; 21(3):661-670. doi: 10.1590/141381232015213.20142015

Brown C, Heller L. Development cooperation in water and sanitation: is it based on the human rights framework? Ciência \& Saúde Coletiva 2017; 22(7): 22472256. https://doi.org/10.1590/1413-81232017227.04872017

Busby J. Water and U.S. National Security. New York: Council on Foreign Relations; 2017.

Cahill $A$. The human right to water - a right of unique status: the legal status and normative content of the right to water. International Journal of Human Rights 2005; 9(3): 389-410. doi: $10.1080 / 13642980500170840$

Carvalho Queiroz V, Coelho de Carvalho R, Heller L. New Approaches to Monitor Inequalities in Access to Water and Sanitation: The SDGs in Latin America and the Caribbean. Water 2020; 12(4): 931. https://doi.org/10.3390/w12040931.

COHRE. Manual on the Right to Water and Sanitation. Geneva: Centre on Housing Rights and Evictions (COHRE)/American Association for the Advancement of Science (AAAS)/Swiss Agency for Development and Cooperation (SDC)/UN-HABITAT; 2007.

Conca K. The United States and International Water Policy. Journal of Environment \& Development 2008; 17(3): 215-237.

De Albuquerque C. Derechos hacia el final. Buenas prácticas en la realización de los derechos al agua y al saneamiento. Relatora Especial sobre el derecho humano al agua potable y al saneamiento; 2012. https://www.ohchr.org/Documents/Issues/Water/BookonGoodPractices_sp.pdf

De Albuquerque C. Manual práctico para la realización de los derechos humanos al agua y al saneamiento. Relatora Especial sobre el derecho humano al agua potable y al saneamiento; 2014. https://intercoonecta.aecid.es/Documentos\%20de\%20la\%20comunidad/Manual_Implementaci \%C3\%B3n\%20Derecho\%20Humano\%20al\%20AyS.pdf

De Luis Romero E, Fernández Aller C, Guzmán Acha C. Derecho humano al agua y al saneamiento: derechos estrechamente vinculados al derecho a la vida. Documentación Social 2013; 170: 217-236.

Dickens C, Rebelo L-M, Nhamo L. Guidelines and indicators for Target 6.6 of the SDGs: Change in the extent of waterrelated ecosystems over time. Report by the International Water Management Institute. Colombo: CGIAR Research Program on Water, Land and Ecosystems; 2017. 


\section{Journal of International Cooperation and Development}

www.richtmann.org/journal

Vol 3, No 2, November 2020

Ezbakhe F. Addressing Water Pollution as a Means to Achieving the Sustainable Development Goals. Journal of Water Pollution and Control 2018; 1(2:6).

Hellum A. Engendering the Right to Water and Sanitation. In M. Langford \& A. Russell (eds.), The Human Right to Water: Theory, Practice and Prospects. Cambridge: Cambridge University Press; 2017. doi:10.1017/9780511862601.011

Ingram G. Adjusting Assistance to the 21st Century. A Revised Agenda for Foreign Assistance Reform. Washington: Brookings Institution; 2014.

FAO. Progress on water use efficiency - Global baseline for SDG 6 Indicator 6.4.1 Rome: FAO/UNWater; 2018.

Gelting R, Bliss K, Patrick M, Lockhart G, Handzel T. Water, Sanitation and Hygiene in Haiti: Past, Present, and Future. American Journal of Tropical Medicine and Hygiene 2013; 89(4): 665670. doi: 10.4269/ajtmh.13-0217

Génevaux C. The Sustainable Development Goals for Water and Sanitation Services. Interpreting the Targets and Indicators. Paris: Programme Solidarité Eau; 2018.

Gleick P.H. The human right to water. Water Policy 1998; 1(5): 487-503. https://doi.org/10.1016/S1366-7017(99)00008-2

Groce N, Bailey N, Lang R, Trani, J-F, Kett M. Water and sanitation issues for persons with disabilities in low- and middle-income countries: A literature review and discussion of implications for global health and international development. Journal of Water and Health 2011; 9(4):617-627. doi:10.2166/wh.2011.198

JICA. Assistance Strategy on Water Supply and Sanitation. Tokyo: Japan International Cooperation Agency; 2012. https://www.wcdrr.org/wcdrr-data/uploads/878/JICA\%E2\%80\%99s \%20Assistance\%20Strategy\%20on\%20Water\%20Supply\%20and\%20Sanitation.pdf

JICA. Cooperation Strategy for Water Resources Sector. Water Supply, Sanitation and Water Resources Management. Tokyo: Japan International Cooperation Agency; 2017. https://www.jica.go.jp/english/our_work/thematic_issues/water/c8h0vm0000ammj2qatt/position_paper.pdf

Kirschner A.J. The Human Right to Water and Sanitation. Max Planck Yearbook of United Nations Law Online 2011; 15(1): 445-487. doi: https://doi.org/10.1163/18757413-90000075

Krchnak K.M. Improving Water Governance Through Increased Public Access to Information and Participation. Sustainable Development Law \& Policy 2005; 5(1): 34-39.

Laituri M, Sternlieb F, Waskom W. A Call to Action: Proposing a University Network for Water, Sanitation, and Hygiene. Journal of Contemporary Water Research \& Education 2010; 145(1): 74-80. https://doi.org/10.1111/j.1936-704X.2010.00085.x

Langford M, Winkler I. Quantifying Water and Sanitation in Development Cooperation: Power or Perversity? Harvard School of Public Health Working Paper Series May 2013; 23:20.

Levin T, Nierenkother M, Odenwalder, N. The Human Right to Water and Sanitation - Translating Theory into Practice. Eschborn: Germany Technical Cooperation Agency; 2009. https://www.ircwash.org/sites/default/files/Levin-2009-Human.pdf

MAEC. Estrategia de la Cooperación Española en Haití 2006-2008. Madrid: Ministerio de Asuntos Exteriores y Cooperación; 2006.

MAEC. Marco de Asociación País España - Haití 2015-2017. Madrid: Ministerio de Asuntos Exteriores y Cooperación; 2015. 


\section{Journal of International Cooperation and Development}

www.richtmann.org/journal

Vol 3, No 2, November 2020

MAEC. Evaluación intermedia del Fondo de Cooperación para Agua y Saneamiento (FCAS). Madrid: Ministerio de Asuntos Exteriores y Cooperación; 2017.

MAEC. V Plan Director de la Cooperación Española 2018-2021. Madrid: Ministerio de Asuntos Exteriores y Cooperación; 2018. http://www.exteriores.gob.es/Portal/es/SalaDePrensa /EIMinisteriolnforma/Documents/V\%20Plan\%20Director\%20de\%20la\%20Cooperacio\%CC\%8 1n\%20Espan\%CC\%83ola.pdf

Mara D. The elimination of open defecation and its adverse health effects: a moral imperative for governments and development professionals. Journal of Water, Sanitation and Hygiene for Development 2017; 7(1): 1-12.

Mara D, Evans B. The sanitation and hygiene targets of the sustainable development goals: scope and challenges. Journal of Water, Sanitation and Hygiene for Development 2018; 8(1): 1-16. https://doi.org/10.2166/washdev.2017.048.

MAUC. Plan de Acción para la Implementación de la Agenda 2030. Hacia una Estrategia Española de Desarrollo Sostenible. Madrid: Ministerio de Asuntos Exteriores, Unión Europea y Cooperación; 2018. http://www.exteriores.gob.es/Portal/es/SalaDePrensa/Multimedia/Publicaciones /Documents/PLAN\%20DE\%20ACCION\%20PARA\%20LA\%20IMPLEMENTACION\%20DE\%20LA\%20 AGENDA\%202030.pdf

Meier BM, Kayser GL, Kestenbaum JG, Amjad UQ, Dalcanale F, Bartram J. Translating the Human Right to Water and Sanitation into Public Policy Reform. Sci Eng Ethics 2014 Dec; 20(4): 833848. doi: 10.1007/s11948-013-9504-x

Meier BM, Kim Y. Human Rights Accountability Through Treaty Bodies: Examining Human Rights Treaty Monitoring for Water and Sanitation. Duke Journal of Comparative \& International Law 2015; 26: 139-228.

Neves-Silva P, Martins G.I, Heller L. Human rights' interdependence and indivisibility: a glance over the human rights to water and sanitation. BMC Int Health Hum Rights 2019; 19(14). https://doi.org/10.1186/s12914-019-0197-3

Obani P, Gupta J. The Evolution of the Right to Water and Sanitation: Differentiating the Implications. Review of European, Comparative \& International Environmental Law 201; 24. doi: $10.1111 /$ reel.12095.

OHCHR. Frequently Asked Questions on a Human Rights-Based Approach to Development Cooperation. Geneva: Office of the United Nations High Commissioner for Human Rights; 2006. https://www.ohchr.org/Documents/Publications/FSheet37_RtD_EN.pdf

OECD. Financing water and sanitation in developing countries: the contribution of external aid. Paris: Organization for Economic Co-Operation and Development -DAC; 2010. https://www.oecd.org/dac/stats/45902160.pdf

OECD. Financing water and sanitation in developing countries: the contribution of external aid. Paris: Organization for Economic Co-Operation and Development -DAC; 2012. http://www.oecd.org/dac/stats/49839924.pdf

OECD. Financing water and sanitation in developing countries: the contribution of external aid. Paris: Organization for Economic Co-Operation and Development -DAC; 2013. http://www.oecd.org/dac/stats/Brochure_water_2013.pdf

OECD. Financing water and sanitation in developing countries: key trends and figures. Paris: Organization for Economic Co-Operation and Development -DAC; 2017. 


\section{Journal of International Cooperation and Development}

www.richtmann.org/journal

Vol 3, No 2, November 2020

ONGAWA. Derecho humano al agua y saneamiento. Enfoque de derechos, equidad de género y medición del progreso. Madrid: ONGAWA/Unesco Etxea; 2012.

Programa de Agua y Saneamiento. Construyendo la equidad de género: metodología e instrumentos para su inclusión en proyectos de agua y saneamiento. Lima: Banco Mundial; 2002.

Saleem M, Burdett T, Heaslip V. Health and social impacts of open defecation on women: a systematic review. BMC Public Health 2019; 19(158). doi: 10.1186/s12889-019-6423-z

Scanlon J, Cassar A, Nemes N. Water as a Human Right? Gland/Cambridge: IUCN; 2004.

Sorroza A. Una apuesta de la diplomacia española: Estrategia del Agua 5+5. Madrid: Real Instituto Elcano; 2014. https://blog.realinstitutoelcano.org/una-apuesta-de-la-diplomacia-espanolaestrategia-del-agua-55/

Thielböguer P. Re-Conceptualizing the Human Right to Water: A Pledge for a Hybrid Approach. Human Rights Law Review 2015; 15: 225-249.

Tortajada C. Contributions of recycled wastewater to clean water and sanitation Sustainable Development Goals. NPJ Clean Water 2020; 3(22). https://doi.org/10.1038/s41545-0200069-3

Tully S. A Human Right to Access Water? A Critique of General Comment No. 15. Netherlands Quarterly of Human Rights 2005; 23(1): 35-63.

UN-Water. Gender, Water and Sanitation: A Policy Brief. Geneva: UN-Water; 2006. https://www.un.org/waterforlifedecade/pdf/un_water_policy_brief_2_gender.pdf

UN-Water. Eliminating Discrimination and Inequalities in Access to Water and Sanitation. Geneva: UN-Water; 2015. https://www.unwater.org/publications/eliminating-discriminationinequalities-access-water-sanitation/

UN-Water. Water and Sanitation Interlinkages across the 2030 Agenda for Sustainable Development. Geneva: UN-Water; 2016. https://www.unwater.org/publications/watersanitation-interlinkages-across-2030-agenda-sustainable-development/

USAID. Water and Development Strategy. Washington: United States Agency for International Development; 2013a. https://www.usaid.gov/sites/default/files/documents/1865 /USAID_Water_Strategy_3.pdf

USAID. Strategy on Democracy, Human Rights and Governance. Washington: United States Agency for International Development; 2013b. https://www.usaid.gov/sites/default/files /documents/1866/USAID-DRG_fina-_6-24-31.pdf

USAID. Water and Development Strategy's Implementation Field Guide. Washington: United States Agency for International Development; 2014. https://files.globalwaters.org/water-linksfiles/Water\%20and\%20Development\%20Strategy\%20Implementation\%20Field\%20Guide\%2 02014.pdf

USAID. USAID Water and Development Country Plan for Haiti. Washington DC: United States Agency for International Development, 2016. https://files.globalwaters.org/water-linksfiles/Haiti\%20Country\%20Plan\%20final.pdf

USAID. USAID/Haiti Strategic Framework 2018-2020. Washington DC: United States Agency for International Development, 2018. https://www.usaid.gov/sites/default/files/documents /1862/USAID-Haiti-Strategic-Framework-2018-2020.pdf 


\section{Journal of International Cooperation and Development}

www.richtmann.org/journal

Vol 3, No 2, November 2020

USAID. Global Water and Development. Report of Water and Sanitation Activities FY 2017. Washington: United States Agency for International Development; 2019. https://www.usaid.gov/sites/default/files/documents/1865/USAID_Global-Water-andDevelopment-Report_FY-2017.pdf

US Department of State. Caribbean 2020: A Multi-Year Strategy To Increase the Security, Prosperity, and Well-Being of the People of the United States and the Caribbean. Washington D.C.: United States Department of State; 2019. https://www.state.gov/wpcontent/uploads/2019/12/WHA-US-Caribbean-2020-Report-web.pdf

U.S. Government. Global Water Strategy. Washington: United States Government; 2017. https://www.usaid.gov/sites/default/files/documents/1865/Global_Water_Strategy_2017_ final_508v2.pdf

Van Wijk-Sijbesma C. Gender in Water Resources Management, Water Supply and Sanitation: Roles and Realities Revisited. Delft: International Research Centre for Water and Sanitation;1998.

WaterAid. Off-track, off-target: Why investment in water, sanitation and hygiene is not reaching those who need it most. London: WaterAid; 2011.

WaterAid. Sanitation and water: Why we need a global framework for action. London: WaterAid; 2008.

WaterAid. Essential element: why international aid for water, sanitation and hygiene is still a critical source of finance for many countries. London: WaterAid; 2015.

Weststrate J, Dijkstra G, Eshuis J, Gianoli A, Rusca M. The Sustainable Development Goal on Water and Sanitation: Learning from the Millennium Development Goals. Social Indicators Research 2019; 143: 795-810. https://doi.org/10.1007/s11205-018-1965-5

Winkler I.T. The human right to sanitation. University of Pennsylvania Journal of International Law 2016; 37(4).

Winpenny J, Trémolet S, Cardone R, Kolker J, Kingdom B, Mountford L. Aid Flows to the Water Sector: Overview and Recommendations. Washington, DC: World Bank; 2016.

WHO/UNICEF. Meeting the MDG drinking water and sanitation target: a mid-term assessment of progress. Joint Monitoring Programme for Water Supply and Sanitation. Geneva/New York: World Health Organization / United Nations Children's Fund; 2004. https://apps.who.int/iris/bitstream/handle/10665/43021/9241562781.pdf?sequence=1

WHO. Economic and health effects of increasing coverage of low cost household drinking-water supply and sanitation interventions to countries off-track to meet MDG target 10. Geneva: World Health Organization; 2007. https://apps.who.int/iris/bitstream/handle/10665/69684 /WHO_SDE_WSH_07.05_eng.pdf?sequence=1\&isAllowed=y

WHO. Global costs and benefits of drinking-water supply and sanitation interventions to reach the MDG target and universal coverage. Geneva: World Health Organization; 2012. https://www.who.int/water_sanitation_health/publications/2012/globalcosts.pdf

World Bank. High and Dry: Climate Change, Water, and the Economy. Washington, DC: World Bank; 2016. https://www.worldbank.org/en/topic/water/publication/high-and-dry-climatechange-water-and-the-economy 